\title{
Editorial
}

Welcome to the autumn 2016 issue of Legal information Management.

Before discussing the content of this issue, I wish to record our sadness at the recent death of our colleague Elaine Wintle. Elaine was the Librarian at Blackstone Chambers, which she joined in 2005. Over a long career she had also worked at the British Institute of International and Comparative Law and at London Metropolitan University. An obituary has been written and will appear in the next issue of this journal.

I also wish to record the sad news of the death of Laurence Bebbington who was the Deputy Librarian at the University of Aberdeen. Laurence had been a law librarian for many years during his career and had worked at a number of leading academic institutions including the Universities of Nottingham and Birmingham. He spoke at BIALL conferences and maintained a particular interest in copyright matters.

\section{KNOWLEDGE MANAGEMENT}

The opening section of this LIM is concerned with knowledge management. The first article is jointly written by Jane Bradbury, Jon Beaumont and Tim Barlow and is entitled, 'An Evolving landscape: from information gatekeeper to knowledge professional'. This piece is based on Jane's inaugural seminar of BIALL's Knowledge Management Group which was delivered in May 2016. The second piece comes from Hélène Russell and is called, 'A Law firm Librarian's guide to KM'. The combination on these two articles provides an excellent introduction and overview of the many issues concerning KM for professionals working in our sector.

\section{SKILLS BENCHMARKING}

A large part of this LIM concerns BIALL's recently published Professional Skills Framework which describes the skills and experience that legal information professionals need in order to perform their role. It also acts as a benchmarking tool in relation to professional development and aims to be an aid in helping managers with appraisal and recruitment processes. One of the reasons for publishing this invaluable document in LIM, was to give it a degree of permanence and status. I'm grateful to the members of the working group for allowing the document to be included in the journal.

\section{CURRENT ISSUES}

Two articles appear under the Current Issues banner. The first is by Clare Cowling, Director of the Legal Records at Risk (LRAR) project which is based at the Institute of Advanced Legal Studies. Her article discusses the way in which modern private sector legal records are more at risk of loss than their historical equivalents. One of the aims of the LRAR project is to raise awareness of the potential commercial and historical value of legal records amassed by practitioners and the need to preserve these documents. The second article, written by Helen Riley, is a topical one for those working with official publications. Her article is entitled, 'The Challenge of printed UK official publications: improving access at Warwick University Library'.

\section{INTERNATIONAL PERSPECTIVES}

The article in this section is a second piece (the first was published in the spring issue) by Margo Jeske, Channarong Itahchomphoo and Emily Landriault, who are joined on this occasion by Michelle Brown, and the subject of their work is, 'Law student views on the principles of a legal research website: a user experience study'.

\section{CONFERENCE REPORT}

Finally, this issue concludes with a 'chatty' piece written by Pattie Punch, from the University of Limerick and a former member of the LIM Editorial Board. In her article, Pattie looks back on the IALL conference that took place in 2015 in Germany and considers how some of the issues discussed at that meeting relate to some of the Brexit concerns that have arisen since. She focuses on the role of law librarians and the wider transnational world in which they find themselves working.

\section{CURRENT AWARENESS}

As ever, 'thanks' go to Katherine Read and Laura Griffiths of the Institute of Advanced Legal Studies for the current awareness section.

\section{ACKNOWLEDGEMENTS}

As the editor of LIM I am very grateful to all the contributors, our colleagues at Cambridge University Press, especially Craig Baxter, and to the members of the LIM Editorial Board including the Chair of that committee, Dunstan Speight, and the team of proof-readers. In particular, I wish to acknowledge with special 'thanks' the help and support given by Dunstan over recent years. His 'term in office' as Chair of the LIM Board came to an end in June. Dunstan will continue to serve on the committee while Loyita Worley, of Reed Smith, has stepped into the Chair's role; and I look forward to working with her into the future. I also wish to thank Julie Doran who recently stepped down from the Board. She had acted as Product Review Editor and had worked on a number of invaluable contributions to LIM during her time on the committee.

David Wills Editor 